\title{
溶接継手を球状黒鉛鋳鉄継手で置換することによる 疲労強度の強化
}

\author{
日高 哲郎 ${ }^{1) *}$ ・野田 尚昭 ${ }^{2)} \cdot$ 佐野 義一 ${ }^{2)}$. 甲斐 信博 ${ }^{1)} \cdot$ 藤本 宏義 ${ }^{1)}$
}

Fatigue Strength Improvement by Replacing Welded Joints with Ductile Cast Iron Joints

Tetsuro Hidaka, Nao-Aki Noda, Yoshikazu Sano, Nobuhiro Kai and Hiroyoshi Fujimoto

Synopsis : In this study fatigue experiments are conducted for ductile cast iron (DCI) to compare with the fatigue strength of cruciform welded joints. Here, several DCI specimens are prepared to have nearly the same fatigue strength in smooth specimens before welding and to have similar cruciform shapes in the welded joints. It is found that the fatigue strength of DCI specimen is about three times larger than that of the welded joint specimens. The fatigue strength improvement can be explained in terms of the small stress concentration factor, notch insensitivity and compressive residual stress generated by shot blasting for DCI joints.

Key words : fatigue strength; ductile cast iron; welded joint; stress concentration; notch insensitivity; residual stress.

\section{1. 緒言}

溶接構造物は溶接部の急熱・急冷による残留応力や形 状・材質の不連続性による応力集中, 溶接欠陥等の影響に より, 疲労破壞の起点となる場合があり, 特に橋梁をはじ めとする土木分野を中心に有用な材料の選定や対策方法が 求められている ${ }^{1,2)}$ 。

これに対し, 球状黒鉛鋳鉄 ${ }^{3,4}$ は鋼材に匹敵する強度・勒 性を有する材料である他 ${ }^{5-7)}$, 鋳造による一体成形が可能 で自由形状成形性に富む特徵を有する。そのため, 急激な 断面変化を避け, 形状要素を起因とする応力集中を低減で きる。また, 砂型鋳造では徐冷することにより, 熱影響に よる残留応力も比較的少なく, 溶接構造物に対して疲労強 度を向上し得る可能性がある。近年では球状黒鉛鋳鉄の疲 労強度優位性に着目し, 溶接構造物を鋳鉄にて一体化した 製品の開発 ${ }^{8,9)}$ も行われている。しかし, 球状黒鉛鋳鉄は一 般的に鋼と比較して疲労強度が低い ${ }^{10,11}$, シャルピー衝撃 值が小さい ${ }^{12-15)}$ ，さらに鋳造欠陥が発生するなどの理由か ら構造部材として敬遠される傾向にある。また, 溶接継手 と球状黒鉛鋳鉄継手の疲労強度を直接比較した実験データ は見当たらない。これらが原因で球状黒鉛鋳鉄は疲労耐久 部材としてほとんど活用されていない現状にある。以上の 背景をふまえ, 本研究では, 溶接継手を球状黒鉛鋳鉄継手 にて一体化した場合の疲労強度を実験的に検証するととも
に, その要因について比較考察する。

\section{2. 荷重非伝達型十字溶接継手の疲労強度特性}

溶接継手の疲労強度はその継手形状や溶接部の仕上げ状 態に依存することから, 継手形状や仕上げ状態ごとに実験 的に求められた強度等級と呼ばれる設計基準強度が定めら れている ${ }^{16)}$ 。今回はその中から溶接継手の実験データが豊 富で，かつ鋳鉄部材としても補強リブ等で頻繁に活用され る形状に近い荷重非伝達型十字溶接継手 ${ }^{16)}$ (Fig.1 参照, 以 下, 鋼溶接継手または単に溶接継手, Welded joint と記す) を比較対象とする。

Stress concentration factor $K_{t}=3.47$
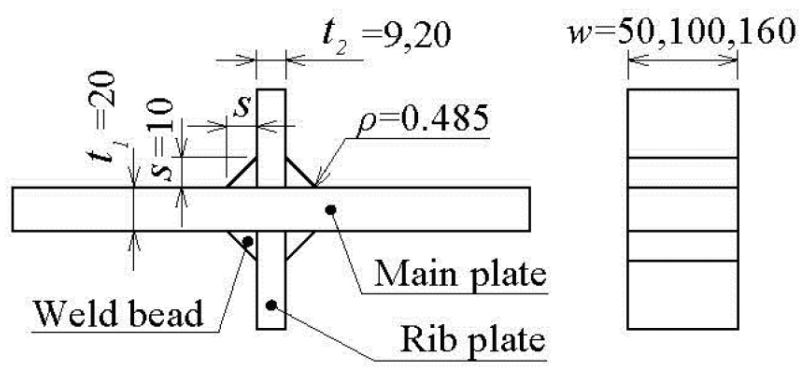

Fig. 1. Dimension of welded joint $\left(t_{1}=20\right)$.

2018年11月26日受付２019年2月15日受理２019年3月14日J-STAGE早期公開 (Received on Nov. 26, 2018; Accepted on Feb. 15, 2019; J-STAGE Advance published on Mar. 14, 2019)

1）日之出水道機器（株）R\&D総合センター（Research and Development Center, Hinode, Ltd., Iwasaki Harakoga Miyaki-cho Miyaki-gun Saga 849-0101）

2) 九州工業大学大学院工学研究院機械知能工学研究系 (Dept. of Mechanical and Control Engineering, Kyusyu Institute of Technology)

* Corresponding author : E-mail : t-hidaka@hinodesuido.co.jp

DOI : https://doi.org/10.2355/tetsutohagane.TETSU-2018-158 
Fig.2にSM50B材の溶接継手とその母材である平滑材 (以降, 鋼平滑材, Steel plate before weldedまたは単にBefore welded と記す）の疲労試験結果 ${ }^{17)}$ を示す。これは, 溶接継 手の設計基準にも多数参照されている, 科学技術庁金属材 料技術研究所の疲れデータシートから引用したデータであ る。溶接継手の試験体形状を Fig.1, 鋼平滑材の試験体形状 をFig.2 中に示す。ここで, 溶接継手の溶接止端部半径 $\rho=$ $0.485 \mathrm{~mm}$ (Fig.1 参照) は, 29本の試験片の平均值であり, グラインダ処理の有無は不明である。Fig.3 は溶接継手のマ クロ組織写真, Table 1 は鋼平滑材の化学成分, Table 2 は鋼 平滑材の機械的性質やFig.2の疲労試験結果についてまと めたものである。Table 2 より, 溶接継手の疲労強度 $\sigma_{w 1}^{\text {STEEL }}$ $=80 \mathrm{MPa}$ は鋼平滑材の疲労強度 $\sigma_{w 0}^{S T E E L}=240 \mathrm{MPa}$ の $30 \%$ と 著しく小さく, 鋼材そのものの疲労強度特性を十分に発揮 できていない。また, 主板厚 (Main plate thickness) $t_{1}$ の増加 によって疲労強度は低下するが，板幅 (Plate width) wやリ ブ厚 (Rib plate thickness) $t_{2}$ が疲労強度に及ぼす影響は小さ いことが知られている ${ }^{18)}$ 。

溶接により疲労強度が低下する要因は, 溶接止端部の形 状的な応力集中や, 溶接部に発生する残留応力があげられ る $^{19-21)}$ 。形状的な応力集中係数 $K_{t}$ は後に示す解析結果から $K_{t}=3.47$ と大きい。 $K_{t}$ 低減には溶接止端部の仕上げを行う など様々な手法があるものの, 現実的にはコスト等の兼ね 合いから，溶接のまま使用されることが多い。残留応力は

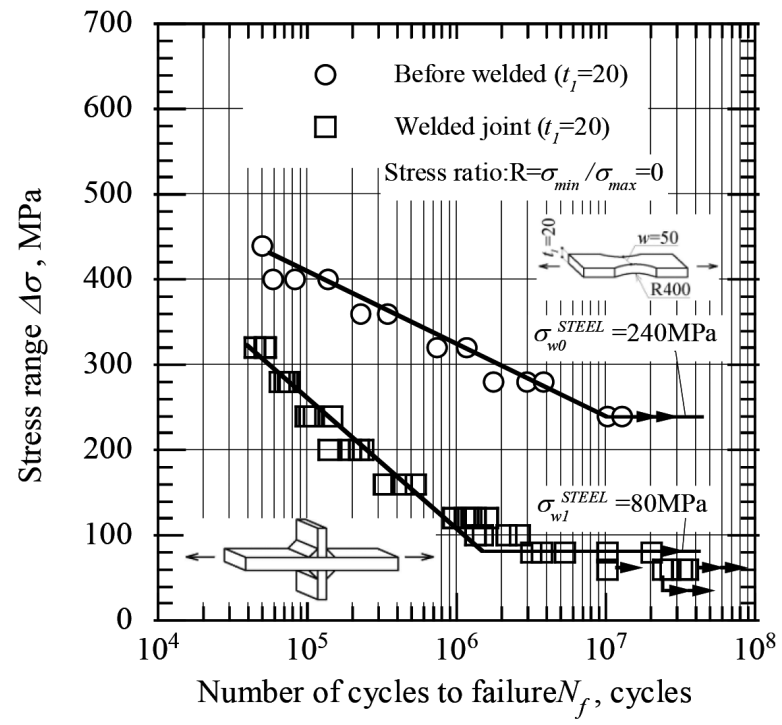

Fig. 2. $S$ - $N$ diagram showing fatigue properties of before welded and welded joint $\left(t_{1}=20\right)$.
Table 2 によぬた溶接継手の実測值は不明であるが，一例 では母材の引張強度が $500 \mathrm{MPa}$ 相当の鋼板を用いて製作 した十字継手の溶接止端部近傍に, 母材の降伏強度に近い 300 400 MPaの引張残留応力が発生しており, 疲労強度低 下の要因となっていることが報告されている ${ }^{22) 。 ~}$

\section{3. 球状黒鉛鋳鉄継手の疲労試験条件}

ここでは, 溶接継手形状を球状黒鉛鋳鉄で一体化した試 験片 (以降, 鋳鉄継手, DCI joint と記す) の寸法と疲労試験 条件について述べる。

\section{$3 \cdot 1$ 球状黒鉛鋳鉄継手疲労試験片}

Fig.4に試験片寸法を示す。主板厚は寸法効果の影響を考 慮し, Fig.1に示した溶接継手の $t_{1}=20 \mathrm{~mm}$ 以上とし, $t_{1}=$ $24 \mathrm{~mm}$ とした。板幅，リブ厚，リブ高さは疲労強度への影 響が小さいため, 試験機の荷重容量や製作上の便宜上, 困 に示す寸法とした。主板とリブの交差部は溶接継手の脚長 $\mathrm{s}=10 \mathrm{~mm}$ (Fig.1 参照) より小さく, かつ鋳造欠陥を考慮し て経験的に $\rho=6 \mathrm{~mm}$ (Fig.4参照)にて滑らかに繋いだ。つ かみ部は補強のため主板厚に対して $9 \mathrm{~mm}$ 増厚した。鋳物 の製作上必要となる抜け勾配は, 主板厚方向に $1^{\circ}$ として設 定した。この抜け勾配による主板の板幅の変化は $0.5 \mathrm{~mm}$ 以下である。なお, 球状黒鉛鋳鉄の平滑材 (以降, 鋳鉄平滑 材またはDCI plateと表記する) の疲労試験には, 便宜上鋳

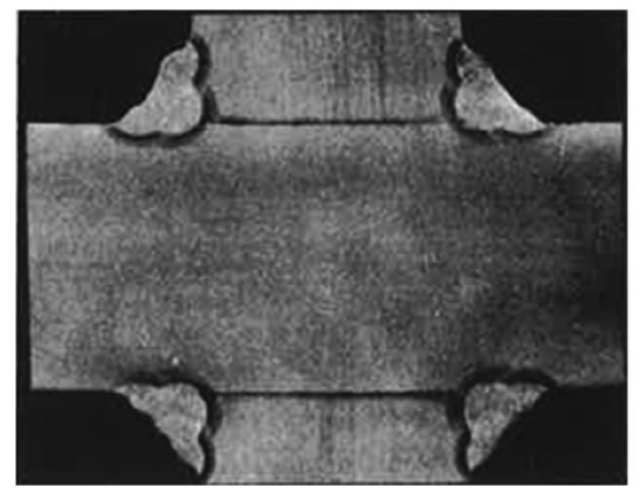

$10 \mathrm{~mm}$

Fig. 3. Macrostructure of welded portion (Etched by nital).

Table 1. Chemical composition of steel plate before welded (wt\%).

\begin{tabular}{c|c|c|c|c|c}
\hline $\mathrm{C}$ & $\mathrm{Si}$ & $\mathrm{Mn}$ & $\mathrm{P}$ & $\mathrm{S}$ & $\mathrm{C}_{\mathrm{eq}}{ }^{*}$ \\
\hline 0.166 & 0.33 & 1.45 & 0.021 & 0.011 & 0.42 \\
\hline
\end{tabular}

*Carbon equivalent $\mathrm{C}_{\mathrm{eq}}=\mathrm{C}+\mathrm{Mn} / 6+\mathrm{Si} / 24+\mathrm{Ni} / 40+\mathrm{Cr} / 5+\mathrm{Mo} / 4+\mathrm{V} / 14$

Table 2. Mechanical and fatigue properties of steel plate before welded and welded joint.

\begin{tabular}{|c|c|c|c|c|c|c|}
\hline \multicolumn{3}{|c|}{ JIS Z 2201 (1968), No.1A type tensile test specimen } & \multicolumn{2}{|c|}{ Steel plate before welded } & \multicolumn{2}{|c|}{ Welded joint } \\
\hline $\begin{array}{l}\text { Upper yield stress } \\
(\mathrm{MPa})\end{array}$ & $\begin{array}{l}\text { Tensile strength } \\
(\mathrm{MPa})\end{array}$ & $\begin{array}{c}\text { Elongation } \\
(\%)\end{array}$ & $\begin{array}{c}\text { Vickers hardness } \\
(H V 98 \mathrm{~N})\end{array}$ & $\begin{array}{l}\text { Fatigue limit } \Delta \sigma \\
(\mathrm{MPa})\end{array}$ & $\begin{array}{l}\text { Vickers hardness* } \\
\text { (HV 98N) }\end{array}$ & $\begin{array}{c}\text { Fatigue limit } \\
(\mathrm{MPa})\end{array}$ \\
\hline 397 & 534 & 31 & 154 & 240 & $225 \sim 250$ & 80 \\
\hline
\end{tabular}

*Maximum hardness of heat affected zone 
鉄継手と同様の十字形状で主板厚 $t_{1}=12 \mathrm{~mm}$ の試験片を用 いている(Fig.4参照)。この試験片は破断位置が全て平滑 部であったため, 鋳鉄平滑材の試験片として代用した。

ここで, 鋳鉄鋳物は通常機械加工は行わず, 鋳肌と呼ば れる鋳造したままの表面状態で使用されることが多い。鋳 肌は砂型表面を転写した際にできる凹凸や砂かみ等の表面 欠陥を含んで扣り, 機械加工面と比較して疲労強度が低下 することが知られている ${ }^{23,24)}$ 。よって今回は, より実用時 の疲労強度に近い結果を得るため, 鋳鉄継手, 鋳鉄平滑材 ともに鋳肌のままで疲労試験を行う。なお, 砂落としのた めのスチールショットブラストは行っている。

鋳鉄継手の化学組成を Table 3 に示す。一般的に疲労強度 は試験体の引張強度と相関があることから, 比較対象であ る溶接継手の引張強度と同等にする必要がある。よって, Table 2 を参照して引張強度が $550 \mathrm{MPa}$ 相当となるよう化学 成分を調整した。鋳鉄継手の機械的性質を Table 4 に示す。 機械的性質はFig. 5 に示すように板状の引張試験片 (JIS14B 号引張試験片）を鋳鉄継手から機械加工にて切り出し, 引 張試験を実施して得られたものである。これらより, 鋳鉄 継手の引張強度や降伏強度に相当する $0.2 \%$ 耐力は Table 2 に示した溶接継手と多少の差異はあるものの, ほぼ同等の 機械的性質であることが確認された。Fig.6に鋳鉄継手のミ クロ組織写真を示す。これより, 本試験片は一般的な球状

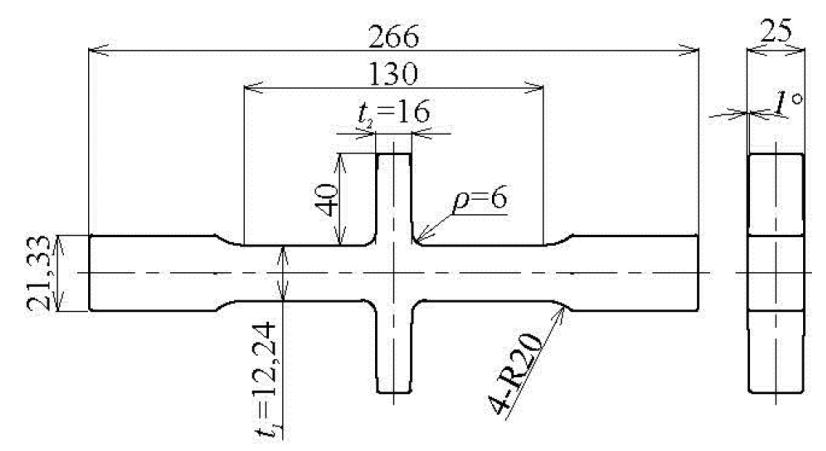

Fig. 4. Dimension of DCI joint.

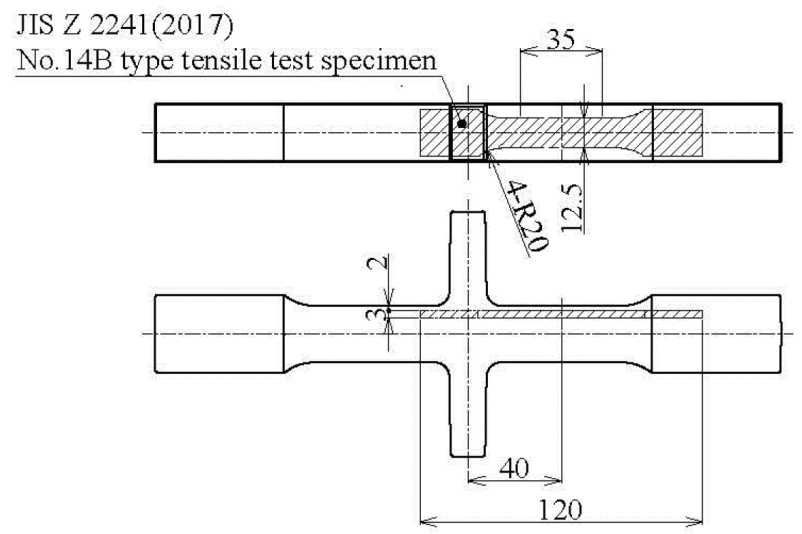

Fig. 5. Dimension and machining location of tensile test specimen.
黒鉛鋳鉄に見られるブルスアイ組織を呈していた。なお， 鋳鉄平滑材 $\left(t_{1}=12 \mathrm{~mm}\right)$ の化学組成, 機械的性質は鋳鉄継 手とほほ同様であった。

\section{$3 \cdot 2$ 疲労試験方法}

繰返し荷重は溶接継手の試験方法に合わせて試験片長手 方向軸引張荷重 (応力比 $\mathrm{R}=0$ ) とし, 荷重容量 $\pm 100 \mathrm{kN}$ 電 気油圧式サーボ疲労試験機（MTS 製）を用いて荷重制御に て実施した。繰返し波形は正弦波, 周波数は $30 \mathrm{~Hz}$ とし, 室 温 $\left(23 \pm 3{ }^{\circ} \mathrm{C}\right) \cdot$ 大気中で行った。最大荷重は試験片耐力を 目安に $350 \mathrm{MPa}$ から順次低下させ, 最大繰返し数 $N_{f}=1.00$ $\times 10^{7}$ 回まで実施し，未破断の場合は試験中止とした。

\section{4. 疲労試験結果}

\section{4・1 球状黒鉛鋳鉄継手の疲労試験結果}

Fig.7 に鋳鉄平滑材と鋳鉄継手の $S-N$ 曲線を示す。四中に は次節の考察のため, Fig. 2 に示した溶接継手や鋼平滑材 のS-N曲線も示している。Table 5 に鋳鉄継手の破断位置, 破断面に確認された破壊起点を示す。表中の試験片No.は Fig.7 中の番号と対応している。No.7*はNo.7の破断面観察 のため, 最大負荷応力を $300 \mathrm{MPa}$ に増大して再度疲労試験 を行い破断させた試験結果である。ここで, Fig.7中に示す No.7*の試験データは $S-N$ 曲線上から大きく離れていない。

Table 3. Chemical composition of DCI joint (wt \%).

\begin{tabular}{c|c|c|c|c|c|c|c}
\hline $\mathrm{C}$ & $\mathrm{Si}$ & $\mathrm{Mn}$ & $\mathrm{P}$ & $\mathrm{S}$ & $\mathrm{Cu}$ & $\mathrm{Mg}$ & $\mathrm{C}_{\mathrm{eq}}{ }^{*}$ \\
\hline 3.67 & 2.45 & 0.41 & 0.024 & 0.004 & 0.31 & 0.042 & 3.84 \\
\hline
\end{tabular}

*Carbon equivalent $\mathrm{C}_{\mathrm{eq}}=\mathrm{C}+\mathrm{Mn} / 6+\mathrm{Si} / 24+\mathrm{Ni} / 40+\mathrm{Cr} / 5+\mathrm{Mo} / 4+\mathrm{V} / 14$

Table 4. Mechanical properties of DCI joint.

\begin{tabular}{c|c|c|c}
\hline \multicolumn{4}{c}{ JIS Z 2241(2017), No.14B type tensile test specimen } \\
\hline $\begin{array}{c}0.2 \% \text { Proof stress } \\
(\mathrm{MPa})\end{array}$ & $\begin{array}{c}\text { Tensile strength } \\
(\mathrm{MPa})\end{array}$ & $\begin{array}{c}\text { Elongation } \\
(\%)\end{array}$ & $\begin{array}{c}\text { Brinell hardness } \\
(\mathrm{HB})\end{array}$ \\
\hline 340 & 560 & 15.8 & 191 \\
\hline
\end{tabular}

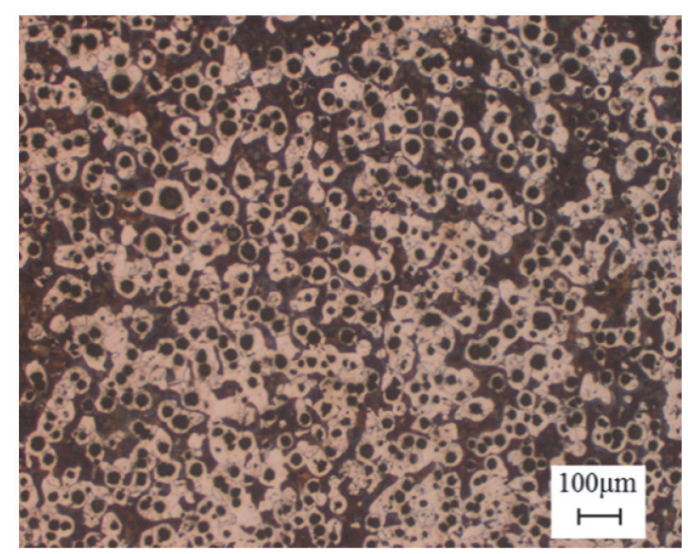

Fig. 6. Microstructure of DCI joint (Etched by nital). (Online version in color.) 
これは最大負荷応力が十分に大きく, コーキシング効果が ほぼないためと考えられる。よってNo.7*も有効なデータ であると判断し，同図に示している。

Fig.7より, 鋳鉄継手の疲労強度は $\sigma_{w 1}^{D C I}=220 \mathrm{MPa}$ が得ら れており, 鋳鉄平滑材の疲労強度 $\sigma_{w 0}^{D C I}=240 \mathrm{MPa}$ に対して 90\%程度であった。

Table 5 より, 破断位置はNo.5を除きリブ交差部もしくは つかみ部近傍 R部の応力集中箇所であった。また，破面の 鋳肌近傍には比較的小さな介在物欠陥が確認され，破面の 様相からこれらの表層欠陷が破壊の起点であることがわか
る。なお，これらの欠陷はマッピング分析により砂かみや 球状化剂等のドロスと呼ばれる欠陷と判断される。欠陥サ イズは球体に換算すると直径 1〜2 mm 程度であった。No.5 は内部の空洞状の大きな欠陷を起点に破壊している。これ は鋳造時の凝固収縮によりしばしば発生する引け巣欠陥と 考えられる。この試験体の破断位置は応力集中部から少し 離れた平行部であった。これは, 他の試験片と異なり, 応 力集中や表層欠陥よりも内部欠陥の影響を強く受けたため と想定できる。このような比較的大きな欠陷については， 試作段階で鋳造方案等を修正し, 許容できる欠陷サイズに

Table 5. Broken position and fracture origin of DCI joint in Fig.7. (Online version in color.)

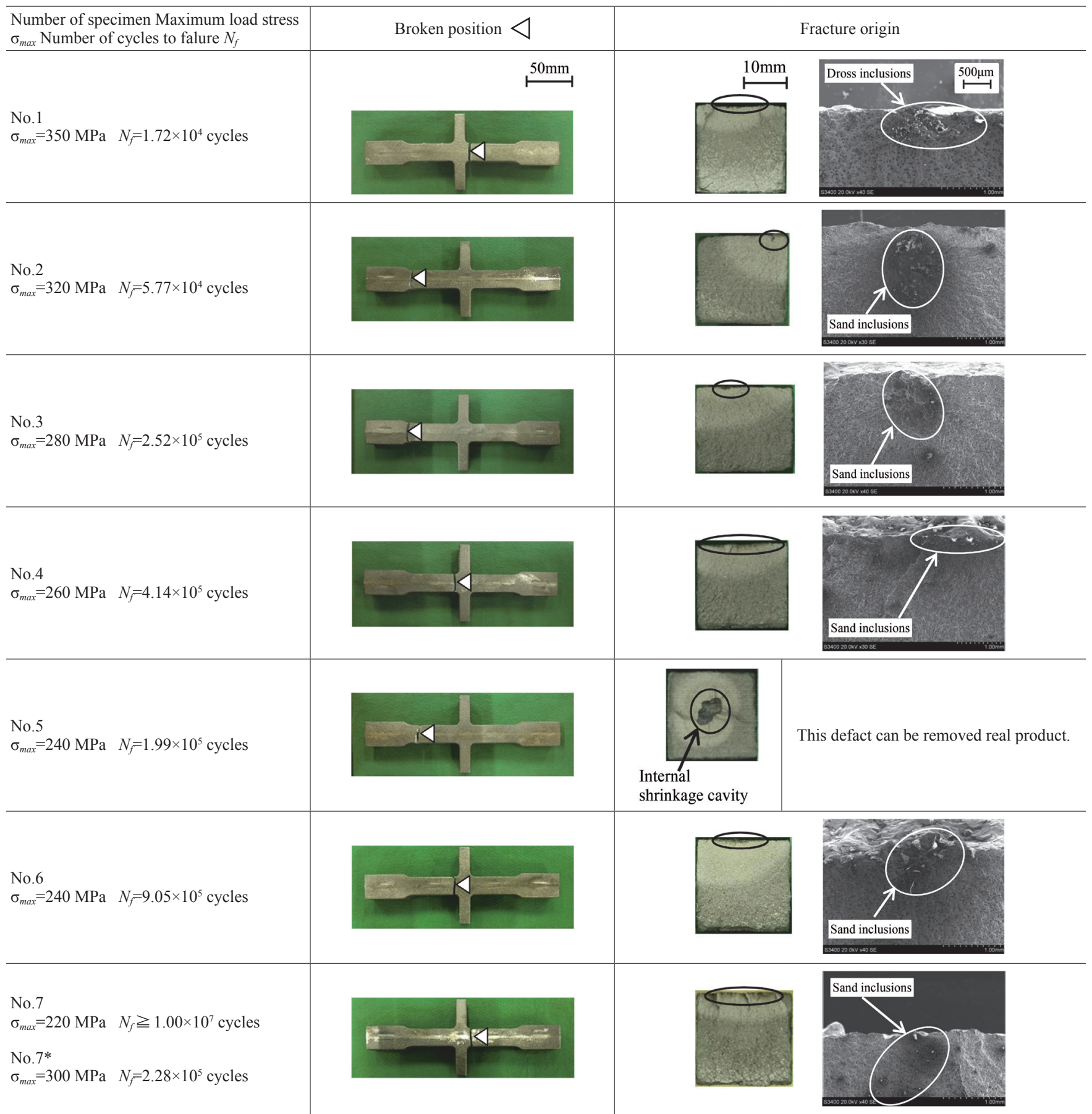


収まるよう抜本的な欠陷対策を行う。その上でロット数に 応じて抜き取りUT検査を実施し，構造的に重要な部位に ついては欠陥サイズが $\varphi 2 \mathrm{~mm}$ 以下となるよう品質管理を 行っている。今回は試験片であることから全数X線検査を 実施し，欠陥の存在を把握した上で試験を行った。なお， No. 5 以外は検出されなかった。

鋳鉄平滑材 $\left(t_{1}=12 \mathrm{~mm}\right)$ の詳細は記述していないが, 破 断位置は全て平行部であり，欠陥サイズは鋳鉄継手 $\left(t_{1}=\right.$ $24 \mathrm{~mm})$ とほぼ同等であった。これらの詳細な考察につい ては今後行うこととする。

\section{$4 \cdot 2$ 球状黒鉛鋳鉄継手と溶接継手の疲労強度比較}

Fig.7より， $\sigma_{w 1}^{\text {STEEL }}=80 \mathrm{MPa}$ であるのに対し， $\sigma_{w 1}^{D C I}=$ $220 \mathrm{MPa}$ が得られており，鋳鉄継手の疲労限度は溶接継 手に対し 2.75 倍の優位性が確認された。また, $\sigma_{w 1}^{D C I} / \sigma_{w 0}^{D C I}=$ $90 \%$ に対し， $\sigma_{w 1}^{S T E L L} / \sigma_{w 0}^{\text {STEEL }}=30 \%$ であり，平滑材に対する低 下率は著しく小さい。

一方, 鋳鉄継手の $S-N$ 曲線の傾きは溶接継手に対して小 さく，切欠き効果が小さいと考えられる。これらの要因は リブ交差部近傍の応力集中や切欠き感受性, 残留応力の違 いが影響していると考えられる。詳細は次章にて考察す る。

\section{5. 球状黒鉛鋳鉄継手の疲労強度が 溶接継手より優れる要因分析}

ここでは, 引張強度が同等である溶接継手と鋳鉄継手の 疲労強度が異なる要因について考察する。

\section{$5 \cdot 1$ 平滑材の疲労強度}

切欠き材である溶接継手と鋳鉄継手を比較する上で基本
となるそれぞれの平滑材の疲労強度や表面状態について改 めて整理して打く。

Table 6 にそれぞれの平滑材の疲労強度と表面状態を示 す。疲労強度はそれぞれ $240 \mathrm{MPa}$ で同じである。表面状態 は鋼平滑材は黒皮, 鋳鉄平滑材は鋳肌であるが, 鋳鉄平滑 材については砂型鋳造後に通常実施する砂落としのための スチールショットブラストを施している。なお，溶接継手， 鋳鉄継手においても表面状態はそれぞれの平滑材と同様で ある。次節以降，これらを前提に考察を行う。

\section{$5 \cdot 2$ 応力集中係数の違い}

形状的な応力集中の影響を比較するため, 溶接継手 $\left(t_{1}=\right.$ 20) と鋳鉄継手 $\left(t_{1}=24\right)$ の FEM解析を行い，リブ交差部近 傍に発生する応力集中係数を調查した。解析コードには市 販の沉用解析ソフト Marc 2012 (MSC Software社製) を用い た。

Fig.8に示すように解析モデルは対称性を考慮して $1 / 4$ 分 割モデルとし，溶接継手についてはフランク角を $45^{\circ}$, 止 端部の曲率半径 $\rho$ は実測されている平均值 ${ }^{17)}$ から $0.485 \mathrm{~mm}$ とした。鋳鉄継手についてはFig.4に示した設計寸法にて モデル化した。境界条件は分割面に対称拘束を，平行部断 面に引張荷重を与えた。

Fig.9に溶接継手と鋳鉄継手の解析結果を最大主応力の

Table 6. Fatigue limit and surface condition of steel plate before welded and DCI plate.

\begin{tabular}{c|c|c}
\hline Specimen type & Fatigue limit $\Delta \sigma(\mathrm{MPa})$ & Surface condition \\
\hline $\begin{array}{c}\text { Steel plate before } \\
\text { welded }\end{array}$ & 240 & Mill scale \\
\hline DCI plate & 240 & Cast skin and shot blast \\
\hline
\end{tabular}

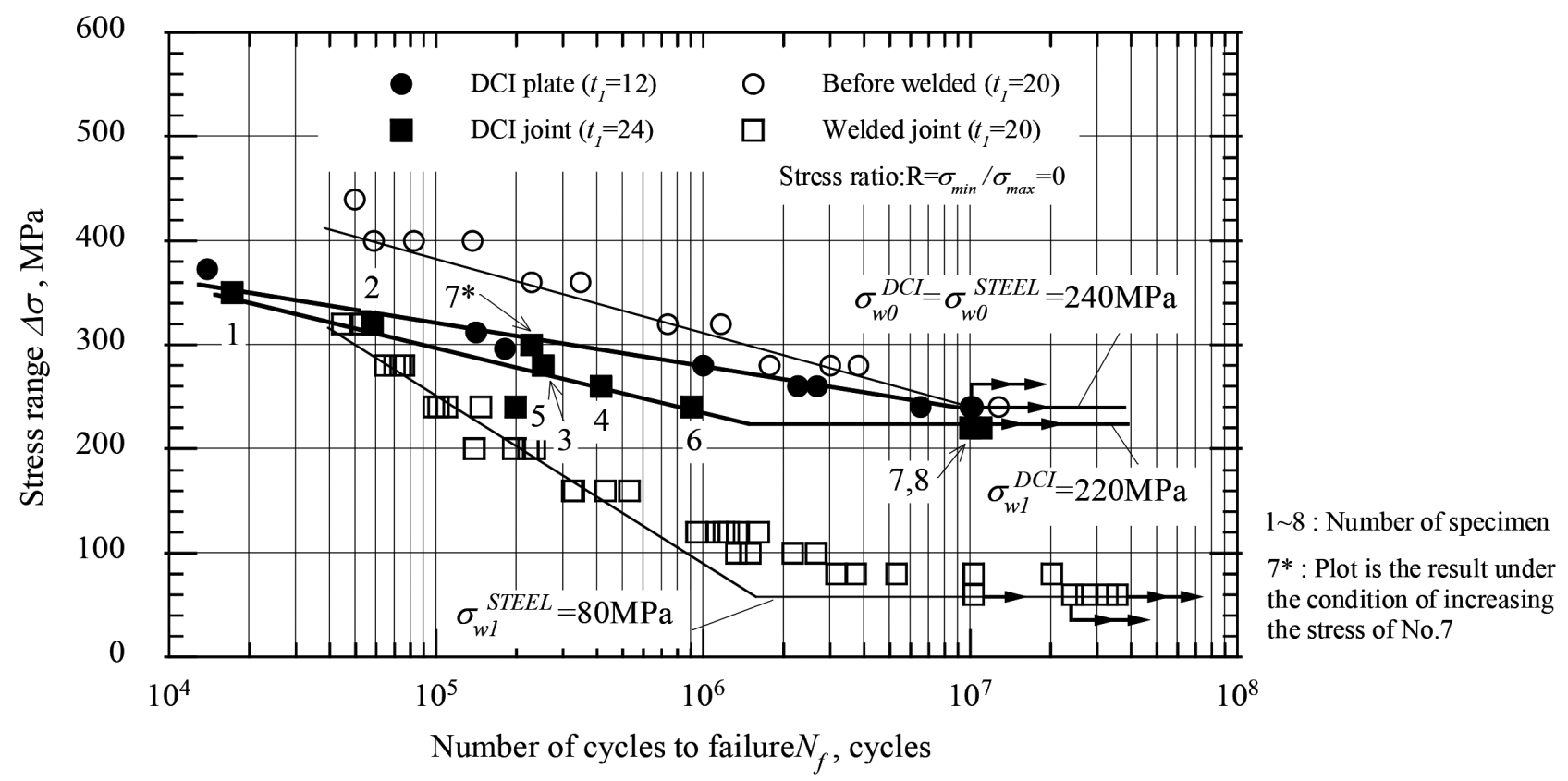

Fig. 7. $S-N$ diagram showing fatigue properties of DCI specimen and steel specimen. 
コンター眓で示す。罒中に示す応力集中係数 $K_{t}$ はリブ交差 部近傍 (フィレット部) の最大応力 $\sigma_{\max }$ を公称応力 $\sigma_{n}$ にて 除して得られる。ここで，フィレットの応力集中問題では 最大応力 $\sigma_{\max }$ が生じる位置と公称応力 $\sigma_{n}$ が生じる位置は異 なる (Fig.10参照) けれども，ここでは一般的に強度設計に 用いられる応力集中係数の定義を用いている ${ }^{25-30)}$ 。

これより，鋳鉄継手の $K_{t}$ は 1.68 であり，溶接継手の $K_{t}=$ 3.47 と比較して小さい。これは鋳鉄継手のリブ交差部が $\mathrm{R}$ 形状によって滑らかに形成されており, 切欠き半径 $\rho$ が大 きいためである。このように，鋳鉄継手は溶接継手に比べ て応力集中係数が小さく, 疲労強度が向上する要因の一つ と考えられる。なお，鋳鉄はこのR形状を設計次第でさら に大きくすることが可能であり，型による形状成形のた め，溶接ビードと比較して製作上のばらつきも少なくする ことができる。よって，さらに応力集中係数を低減するこ とが可能である。

\section{$5 \cdot 3$ 切欠き感受性の違い}

Fig.7に示したように, $\sigma_{w 0}^{D C I}=240 \mathrm{MPa}, \sigma_{w 1}^{D C I}=220 \mathrm{MPa}$ で あり，今回の疲労試験に打いて，鋳鉄は切欠きの影響をほ とんど受けていない。これは鋳鉄が切欠きに対して鈍感 であることが要因と考えられる。Fig.11 は応力勾配 $\chi$ と切 欠き底の弾性最大応力 $\sigma_{\max }$ の関係を示したもので，種々の 切欠き半径 $\rho$ に対する鉄系材料の切欠き鈍感性を表して いる ${ }^{31,32)}$ 。FCD550（引張強度 $\sigma_{B}=550 \mathrm{MPa}$ 相当の球状黒 鉛鋳鉄) の曲線はデータが見あたらないので, $\mathrm{S} 10 \mathrm{C}\left(\sigma_{B}=\right.$

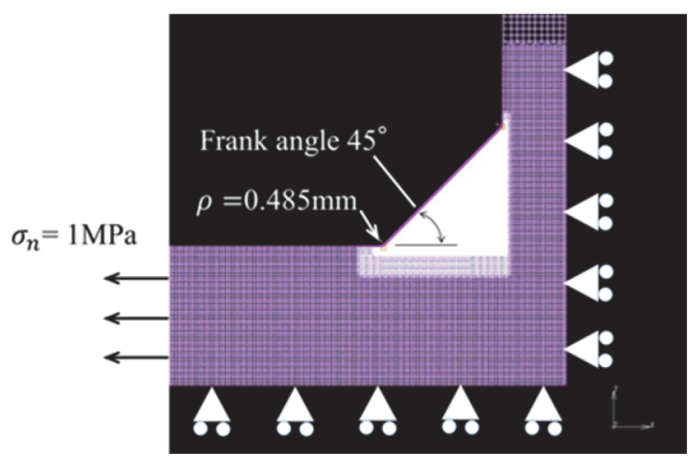

(a) FEM model welded joint $\left(t_{1}=20\right)$

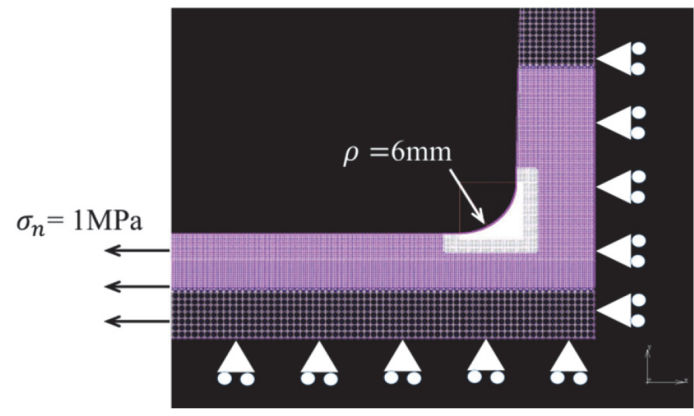

(b) FEM model DCI joint $\left(t_{1}=24\right)$

Fig. 8. FEM model and boundary conditions. (Online version in color.)
$372 \mathrm{MPa})$ と $\mathrm{S} 30 \mathrm{C}\left(\sigma_{B}=537 \mathrm{MPa}\right)$ の引張強度と $\sigma_{\max } / \sigma_{w 0}$ の比 を用いて FCD700 $\left(\sigma_{B}=730 \mathrm{MPa}\right)$ の曲線から予測したもの である。これより, 球状黒鉛鋳鉄である FCD550 P FCD700 は軟鋼の S10C P S30C と比較すると, 応力勾配 $\chi$ が同じで あれば疲労破壊する最大応力 $\sigma_{\text {max }}$ が大きく, 切欠きに対し て非常に鈍感であることがわかる。

ここで, $\sigma_{\max } / \sigma_{w 0}=K_{t} \sigma_{w 1} / \sigma_{w 0}$ で表され, $K_{t}$ は応力集中係数, $\sigma_{w 1}$ は切欠き材の瘦労強度, $\sigma_{w 0}$ は平滑材の㽻労強度である。 図中の破線は応力勾配 $\chi$ に関わらず $K_{t} \sigma_{w 1} / \sigma_{w 0}=1$, 切欠き 係数 $K_{f}=\sigma_{w 0} / \sigma_{w 1}$ であるから, $K_{t}=K_{f}$ の関係にあり, 疲労強 度に対する切欠き感受性が非常に敏感であることを意味し ている。このことは，ばね鋼 (spring steel) ${ }^{33)}$ がこれに近い ことからも理解できる。逆に $\chi$ が大きい範囲となる鋭い切

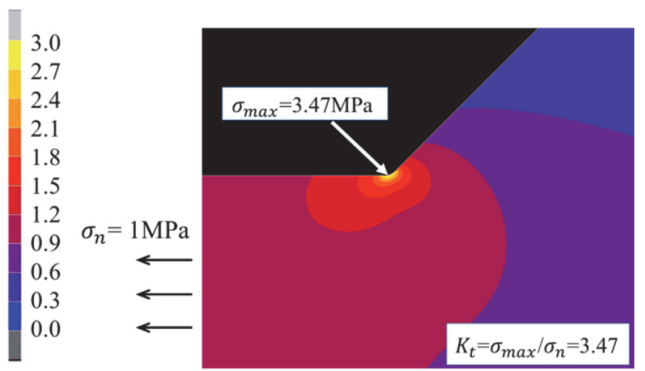

(a) The maximum principal stress distribution of welded joint $\left(t_{1}=20\right)$

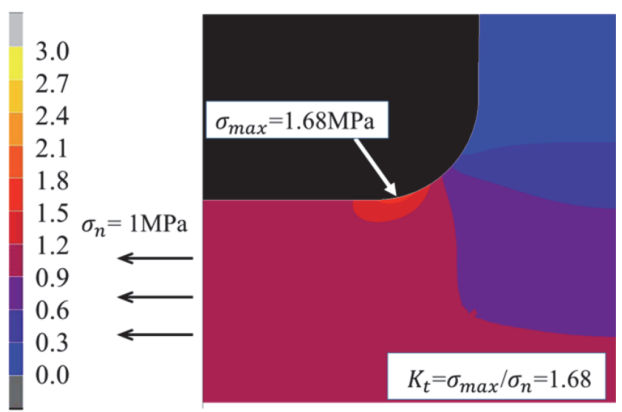

(b) The maximum principal stress distribution of DCI joint $\left(t_{1}=24\right)$

Fig. 9. Results of stress simulation by 2D FEM. (Online version in color.)

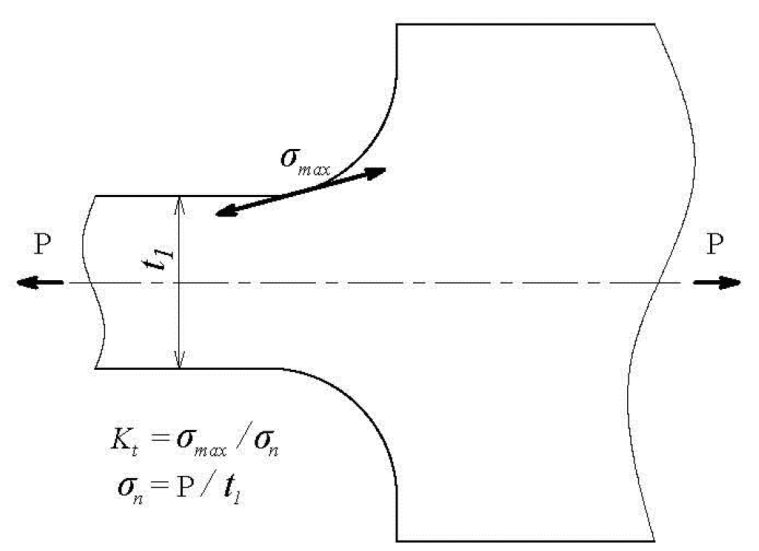

Fig.10. Stress concentration factor of a stepped flat bar with shoulder fillets. 
欠きでも $\sigma_{\text {max }} / \sigma_{w 0}=K_{t} / K_{f}$ が大きい材料は切欠きに対して鈍 感であるといえる。なお, 鉄鋼材料の切欠き感受性は, 化 学組成や基地組織が著しく異なる場合を除き, 引張強度と の相関が強いことが知られている33。

以上をふまえ，溶接継手について，母材であるSM50B と 引張強度が近いS30Cを参考にすると, Fig. 11 より $\chi=2 / \rho$ $=2 / 0.485(\cong 4.12)$ となるから, $K_{t} \sigma_{w 1} / \sigma_{w 0} \cong 1.19$ である。前 節の解析結果より, $K_{t}=3.47$ であるから, $\sigma_{w 1} / \sigma_{w 0} \cong 0.34$ と なり，この溶接継手の疲労強度は平滑材に対して $34 \%$ の疲 労強度を有すると考えられる。よって, 鋼平滑材の疲労強 度は $240 \mathrm{MPa}$ より, 溶接継手の疲労強度は $82 \mathrm{MPa}$ と予測で きる。

一方，鋳鉄継手は $\chi=2 / \rho=2 / 6(\cong 0.33)$ であるから， Fig.11の FCD550を参考にすると $K_{t} \sigma_{w 1} / \sigma_{w 0} \cong 1.13$ である。 $K_{t}=$ 1.68 であるから, $\sigma_{w 1} / \sigma_{w 0} \cong 0.67$ となり, 鋳鉄平滑材の疲労強 度 $240 \mathrm{MPa}$ より鋳鉄継手の疲労強度は $161 \mathrm{MPa}$ と予測でき, 溶接継手の 2 倍程度となる。

以上のことから, 球状黒鉛鋳鉄は軟鋼と比較して切欠き に対して鈍感であり，今回比較した試験片形状から予測さ

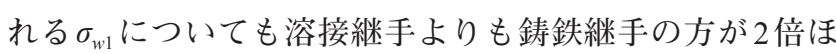
ど大きいことから, 疲労強度が大きく向上したと考えられ る。

\section{$5 \cdot 4$ 残留応力の違い}

Table 7 に溶接継手と鋳鉄継手の残留応力測定值と測定 箇所を示す。測定箇所は溶接継手, 鋳鉄継手ともに繰返し 荷重作用時に最大応力が発生するリブ交差部近傍である。

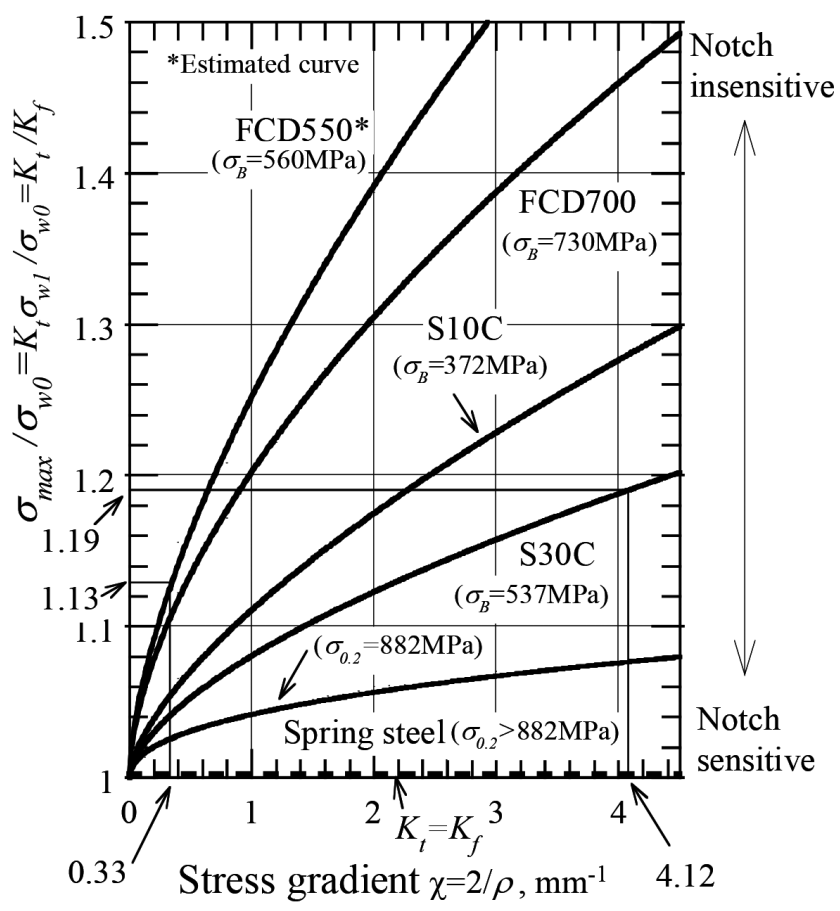

Fig. 11. Notch insensitivity (Relationship between the stress gradient and the maximum elastic stress at a notch root).
溶接継手の測定值は，他の文献でほぼ同形状で，機械的性 質も同等である SM490B の溶接継手の測定結果 ${ }^{34)}$ を引用し て打り, Table 7にある $\mathrm{A} \sim \mathrm{D}$ の 4 点の平均值として示した。 鋳鉄継手は疲労試験を行った試験片と同ロットで鋳造した ものから 3 本選定し, 1 点ずつ測定した平均值である。測定 にはX線残留応力測定装置を用い, Table 8 に示す測定条件 とした。な报, 溶接継手, 鋳鉄継手ともに疲労試験実施前 に残留応力を測定している。

これらの結果から, 溶接継手は $100 \mathrm{MPa}$ の残留応力が発 生していることがわかる。溶接残留応力は 200～300 MPa と大きな場合もあるが，今回の測定值はそれに比べると 小さい。これは, 測定箇所が溶接止端部から $3 \mathrm{~mm}$ 離れて いることが要因と考えられ, 溶接止端部はさらに大きな 残留応力が発生していると推察される。一方, 鋳鉄継手は $300 \mathrm{MPa}$ 以上の大きな圧縮残留応力が発生している。これ は試験片の製作過程で施したスチールショットブラスト処 理の影響と考えられる。過去の研究に扔いても, 同处理に よりほぼ同等の圧縮残留応力が確認されている ${ }^{35,36) 。}$

ここで, これらの残留応力が疲労強度に及ぼす影響を考 える。残留応力は, 繰返し応力が作用すると減衰する場合

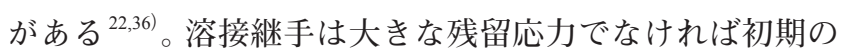
残留応力で考えることが通例である ${ }^{22)}$ 。今回は溶接継手に 発生している残留応力が $100 \mathrm{MPa}$ と比較的小さいことか ら, 溶接継手についてはTable 7に示した疲労試験前の残

Table 7. Residual stress and measuring point of welded joint and DCI joint.

\begin{tabular}{c|c|c}
\hline Specimen type & $\begin{array}{c}\text { Residual stress } \\
\sigma_{\text {res }}(\mathrm{MPa})\end{array}$ & \\
\hline \multirow{2}{*}{ Welded joint } & 100 & Measuring point \\
\hline DCI joint & -305 & \\
\hline
\end{tabular}

Table 8. Residual stress measurement condition of DCI joint.

\begin{tabular}{c|c}
\hline X-ray & $\mathrm{CrK} \alpha$ \\
\hline Diffraction plane & $\mathrm{Fe}(211)$ \\
\hline Filter & $\mathrm{V}$ \\
\hline Stress constant $(\mathrm{MPa} /$ deg.) & -323 \\
\hline Tube voltage $(\mathrm{kV})$ & 30 \\
\hline Tube current $(\mathrm{mA})$ & 10 \\
\hline Collimator $(\mathrm{mm})$ & 2 \\
\hline Incident angle $\varphi_{0}(\mathrm{deg})$. & 0 \\
\hline Measuring method & Half height breadth \\
\hline
\end{tabular}


留応力を用いることとする。一方，鋳肌にショットブラス 卜を施した際の残留応力分布は，表層近傍が最大で，深さ に応じて低下する。また，応力振幅や応力比の影響により

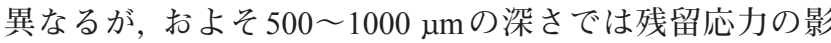
響はほぼなくなるという報告がある ${ }^{36)}$ 。今回は破壊起点と なった欠陥サイズが $1000 \mu \mathrm{m}$ 以上で, 残留応力の影響を受 けない欠陮深さになる場合が想定されるため, Table 7に示 したー305 MPaの抢よそ半分であるー150 MPaの残留応力 が作用していることとする。

両振り疲労強度 $\sigma_{w}$ を式 (1) のように引張強度 $\sigma_{B}$ の 0.48 倍 ${ }^{37)}$ と見積もると, 溶接継手と鋳鉄継手の疲労限度線図は Fig.12のようになる。図中の $\sigma_{1}$ は $\sigma_{w}$ を基準とした片振り疲 労強度であり，式（2）で表される。 $\sigma_{2}$ は $\sigma_{1}$ を基準として残 留応力 $\sigma_{r e s}$ が平均応力として作用した場合の疲労強度であ り，式 (3) で表される。これらより，残留応力による疲労 強度の増減率は $\sigma_{2} / \sigma_{1}$ で表すことができ，己れを式 (4) のよ うに $C_{r}$ と定義する。Fig.12より，溶接継手は残留応力によ り疲労強度が 0.72 倍 $\left(C_{r}=0.72\right)$ になる一方, 鋳鉄継手は 1.40 倍 $\left(C_{r}=1.40\right)$ になることがわかる。以上のことから, 残留応力の観点からも鋳鉄継手は溶接継手に対し疲労強度 が向上すると考えられる。

$$
\begin{aligned}
& \sigma_{w}=0.48 \sigma_{B} \ldots \ldots \ldots \ldots \ldots \ldots \ldots \ldots \ldots \ldots \ldots \ldots \ldots \ldots \\
& \sigma_{1}=\sigma_{w} /\left(1+\sigma_{w} / \sigma_{B}\right) \ldots \ldots \ldots \ldots \ldots \\
& \sigma_{2}=\sigma_{w}\left\{1-\left(\sigma_{1}+\sigma_{r e s}\right) / \sigma_{B}\right\} \cdots \\
& C_{r}=\sigma_{2} / \sigma_{1} \ldots \ldots \ldots \ldots \ldots \ldots \ldots
\end{aligned}
$$

$\sigma_{w}:$ 両振り疲労強度 $(\mathrm{MPa})$

$\sigma_{B}:$ 引張強度 $(\mathrm{MPa})$

$\sigma_{r e s}:$ 残留応力 $(\mathrm{MPa})$

$\sigma_{1}:$ 残留応力がない場合の疲労強度 $(\mathrm{MPa})$

$\sigma_{2}:$ 残留応力がある場合の疲労強度 $(\mathrm{MPa})$

$C_{r}$ : 残留応力による疲労強度の增减率

\section{$5 \cdot 5$ 各種要因が疲労強度に及ぼす効果}

Fig.13は本章のまとめとして, 疲労強度に影響を及 ぼす各種要因の効果を模式的に表したものである。溶 接継手，鋳鉄継手ともに平滑材の疲労強度を基準と して模式的に示している。要因とその効果は，本章で 考察した (1)応力集中係数 ( $K_{t}$ effect)，(2)切欠き鈍感性 $(\chi$ effect $)$, (3)残留応力 $\left(\sigma_{\text {res }}\right.$ effect $)$ である。溶接継手は (1) $K_{t}$ effectにより鋼平滑材から疲労強度が著しく低下する $(240 \mathrm{MPa} \Rightarrow 69 \mathrm{MPa})$ 。(2) $\chi$ effectによりやや疲労強度は 向上するものの $(69 \mathrm{MPa} \Rightarrow 82 \mathrm{MPa})$, その効果は小さく, (3) $\sigma_{\text {res }}$ effectによりさらに疲労強度が低下寸ると考えられ る $(82 \mathrm{MPa} \Rightarrow 59 \mathrm{MPa})$ 。この結果，溶接継手の疲労強度は $59 \mathrm{MPa}$ と予測でき, 平滑材の疲労強度 $240 \mathrm{MPa}$ の $25 \%$ 程度
まで著しく低下する。

一方，鋳鉄継手は (1) $K_{t}$ effectにより疲労強度が低下する が，元の効果は小さく $(240 \mathrm{MPa} \Rightarrow 143 \mathrm{MPa})$, (2) $\chi$ effect の効果もあって $(143 \mathrm{MPa} \Rightarrow 161 \mathrm{MPa})$, 鋳鉄継手の疲労強 度は $161 \mathrm{MPa}$ と予測でき，鋳鉄平滑材のおよそ67\%を確 保している。ここで, 鋳鉄継手は(3) $\sigma_{\text {res }}$ の影響を同様に受 けている鋳鉄平滑材が基準であるため, その効果は図中 には表記していない。以上のことから, 鋳鉄継手の疲労強 度は予測值においても溶接継手の 2.7 倍程度あり, 疲労強 度優位性があることは明らかである。また, 鋳鉄継手の切 欠き係数 $K_{f}^{D C I}=\sigma_{w 0}^{D C I} / \sigma_{w 1}^{D C I}$ は溶接継手の切欠き係数 $K_{f}^{S T E E L}=$

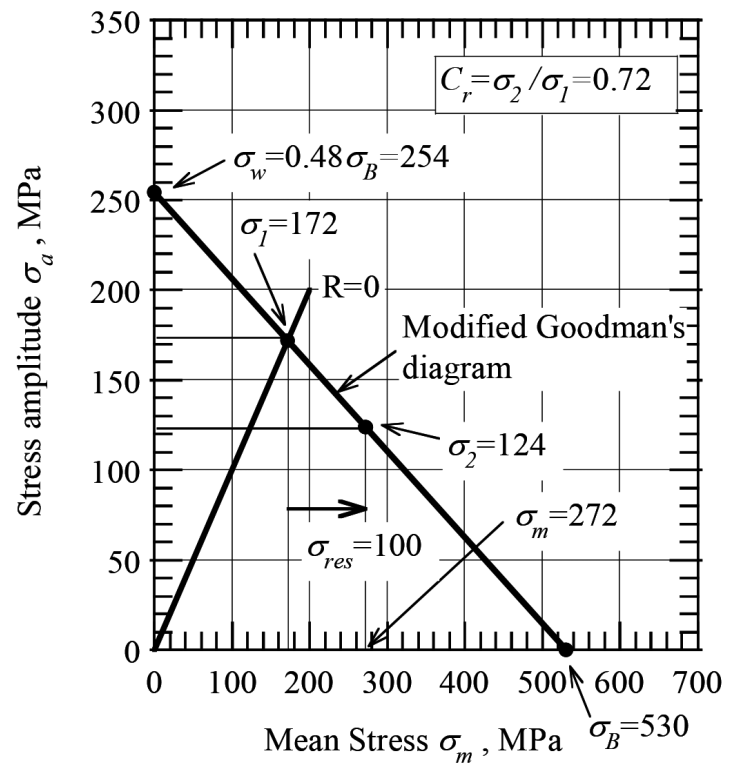

(a) Welded joint

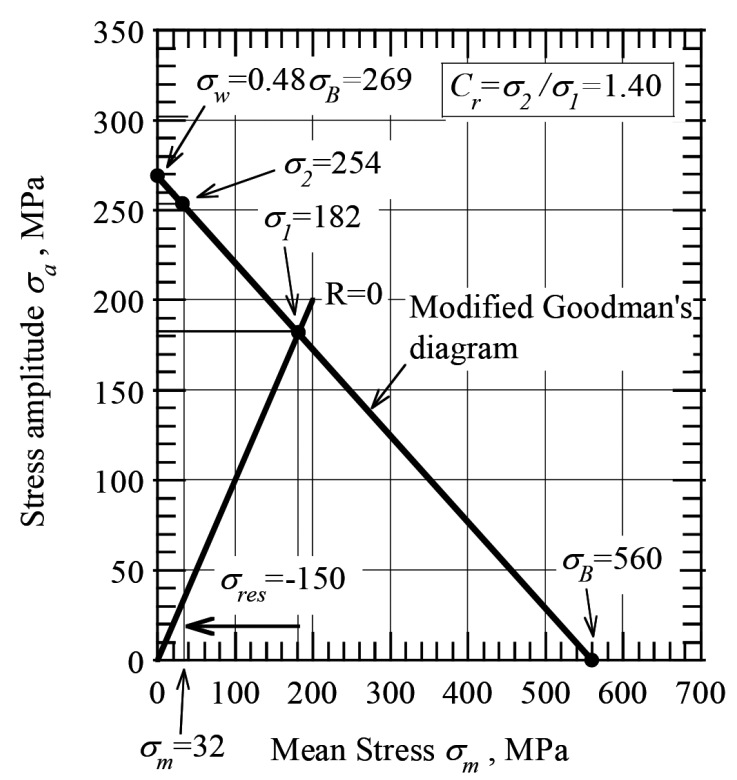

(b) DCI joint

Fig. 12. Fatigue limit diagram showing the effect of residual stress. 
$\sigma_{w 0}^{S T E E L} / \sigma_{w 1}^{S T E E L}$ のおよそ $1 / 3$ であり, 切欠き感受性も鈍感であ ることがわかる。なお，これらの予測值はFig.7に示した実 験值に対し $25 \%$ 程度の違いで一致する。

\section{6. 結言}

主板厚や引張強度と平滑材の疲労強度が同等である溶接 継手と球状黒鉛鋳鉄継手の疲労強度を比較した結果, 以下 の結論を得た。

(1) 鋳鉄継手の疲労強度は $\sigma_{w 1}^{D C I}=220 \mathrm{MPa}$ であり, 溶接継 手の疲労強度 $\sigma_{w 1}^{\text {STEEL }}=80 \mathrm{MPa}$ と比較して 2.7 倍ほど大 きいことを実験的に明らかにした。

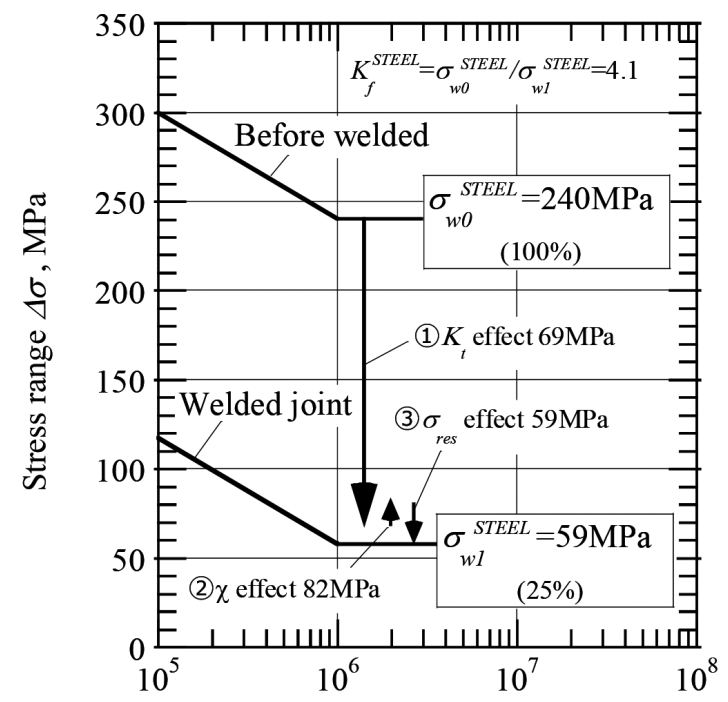

Number of cycles to failure $N_{f}$, cycles (a) Welded joint

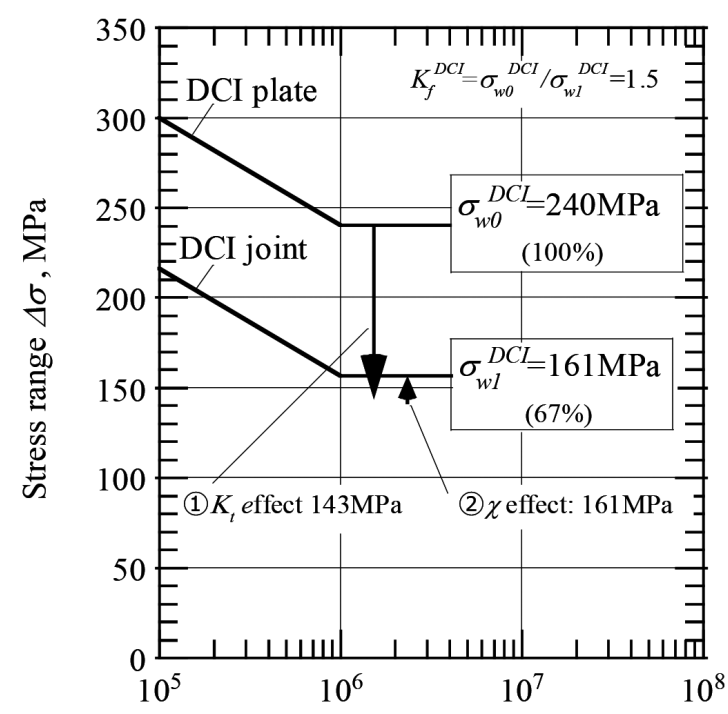

Number of cycles to failure $N_{f}$, cycles

(b) DCI joint

Fig. 13. Effects of various factors on fatigue limit.
（2）疲労強度に影響を及ぼす要因を考察し，その効果を定 量的に検討した。それらの結果を用いて算出した疲労 強度の予測值は, 鋳鉄継手が $\sigma_{w 1}^{D C I}=161 \mathrm{MPa}$, 溶接継手 が $\sigma_{w 1}^{\text {STEEL }}=59 \mathrm{MPa}$ であった。これより, 予測值におい ても鋳鉄継手の疲労強度は溶接継手に対し 2.7 倍ほど 大きい結果となった。

（3）上記 (1),（2）の要因として, 鋳鉄継手は溶接継手と比 較して応力集中係数が小さく, 切欠きに対して鈍感で ある, 表面にショットブラストの圧縮残留応力がある ことがあげられる。

\section{7. 今後の展開}

鋳鉄継手は欠陥が破壊起点となっているが，この影響の 詳細ついては今回考察していない。また，鋳肌の表面粗さ はかなり大きく，この影響についても検討する必要があ る。

以上のことから, 今後は鋳鉄継手の最大欠陥サイズや表 面粗さの影響を考慮した上で疲労強度の下限值を予測し, 溶接継手の疲労強度と比較する。

\section{謝辞}

本研究は平成 29 年度基礎研究等助成金事業 (佐賀県技術 振興等補助金産学官連携技術革新支援事業) の援助を得て 実施された。ここに深く感謝の意を表する。

\section{文献}

1 ) C.Miki, H.Suganuma, M.Tomizawa and F.Machida: Proc. Jpn. Soc. Civ. Eng., 780(2005), 57 (in Japanese).

2 ) S.Ono, Y.Hirabayashi, T.Shimozato, N.Inaba, M.Murano and T.Miki: Proc. Jpn. Soc. Civ. Eng. A, 65(2009), 335 (in Japanese).

3 ) J.M.Borrajo, R.A.Marti nez, R.E.Boeri and J.A.Sikora: ISIJ Int., 42(2002), 257.

4 ) R.Ivanova, W.Sha and S.Malinov: ISIJ Int., 44(2004), 896.

5 ) B.Bosnjak, B.Radulovic, K.P.Tonev and V.Asanovic: ISIJ Int., 40(2000), 1246.

6 ) M.Takanezawa, Y.Tomota and Y.Kobayashi: ISIJ Int., 38(1998), 106.

7 ) M.D.Echeverría, O.J.Moncada and J.A.Sikora: ISIJ Int., 41(2001), 25.

8 ) H.Tobinaga, M.Murayama, E.Saeki, T.Tamakoshi, E.Yamaguchi and C.Miki: Kou kouzou ronbunshuu, 24(2017), 95_13 (in Japanese).

9 ) M.Yano: J. Jpn. Foundrymen's Soc., 77(2005), 641 (in Japanese).

10) I.Ovali, V.Kilicli and M.Erdogan: ISIJ Int., 53(2013), 375.

11) H.Shirasawa: ISIJ Int., 34(1994), 285.

12) P.J.J.Ratto, A.F.Ansaldi, V.E.Fierro, F.R Agüera, H.N.A.Villar and J.A.Sikora: ISIJ Int., 41(2001), 372.

13) A.Basso, M.Caldera, G.Rivera and J.Sikora: ISIJ Int., 52(2012), 1130.

14) Z.Liu, G.Zhou, Y.Qiu and G.Wang: ISIJ Int., 50(2010), 531.

15) N.Tsunekage and H.Tsubakino: ISIJ Int., 41(2001), 498.

16) 鋼構造物の疲労設計指針·同解説, 日本鋼構造協会編, 技報堂, 東京, (2012), 33.

17) 金属材料技術研究所疲れデータシート, No.13, 科学技術庁金 属材料技術研究所, 東京, (1979), 1.

18) M.Kamakura, M.Nihei, E.Sasaki, M.Kanao and M.Inagaki: J. Jpn. 
Weld. Soc., 48(1979), 1060 (in Japanese).

19) M.Ohata: J. Jpn. Weld. Soc., 77(2008), 50 (in Japanese).

20) C.M.Sonsino: Int. J. Fatigure, 31(2009), 88.

21) E.Harati, L.Karlsson, L-E.Svensson and K.Dalaei: Int. J. Fatigue, 77(2015), 160

22) K.Matsuoka, I.Takahashi, T.Yoshii and E.Fujii: Q. J. Jpn. Weld. Soc., 9(1991), 36 (in Japanese).

23) T.Shiota, M.Hatate and K.Takemoto: J. JFS., 69(1997), 904 (in Japanese).

24) S.Boonmee, M.K.Moran and D.M.Stefanescu: American Foundry Society, Schaumburg, IL USA, (2011), 11

25) 兼田楨宏, 山本雄二 : 基礎 機械設計工学, 理工学社, 東京, (1995), 18.

26) R.E.Peterson: Stress Concentration factor, John Wiley \& Sons, New York, (1974), 96

27) N.-A.Noda, T.Saeki and H.Nishitani: Trans. Jpn. Soc. Mech. Eng. A, 55(1989), 69 (in Japanese).

28) N.-A.Noda, Y.Takase and K.Monda: Int. J. Fatigue, 19(1997), 75.
29) N.-A.Noda and Y.Takase: Fatigue Fract. Eng. Mater. Struct., 26(2003), 245

30) N.-A.Noda and Y.Takase: J. Test. Eval., 32(2004), 217.

31) H.Nishitani, H.Noguchi, H.Uchihori and H.Nakae: Trans. Jpn. Soc. Mech. Eng. A, 54(1988), 1293 (in Japanese).

32) H.Nishitani, S.Uchiyama, H.Nakae and H.Noguchi: Trans. Jpn. Soc Mech. Eng. A, 58(1992), 2280 (in Japanese).

33) 村上敬宜 : 金属疲労 微小欠陥と介在物の影響, 養賢堂, 東京, (2014), 27.

34) 物質・材料研究機構疲労データシート, No.91, 物質・材料研 究機構, 東京, (2003), 4

35) S.Aoyama, M.Ito and S.Asami: J. Soc. Mater. Sci., Jpn., 27(1978), 895 (in Japanese).

36) J.Yamabe, M.Kobayashi and N.Nakajima: Trans. Jpn. Soc. Mech. Eng. A, 71(2005), 1690 (in Japanese).

37) K.Asami and Y.Kitsunai: J. Soc. Mater. Sci., Jpn., 35(1986), 550 (in Japanese). 